\title{
Hormonal therapeutic strategy on the induction of accessory corpora lutea in relation to follicle size and on the increase of progesterone in sheep
}

\author{
J. Fernandez ${ }^{\text {a, }}$, M.M. Bruno- Galarraga ${ }^{\text {a }}$, A.T. Soto ${ }^{\text {b }}$, R.L. de la Sota ${ }^{\text {b }}$, M.I. Cueto ${ }^{\text {, }}$ \\ I.M. Lacau ${ }^{\mathrm{c}}$, A.E. Gibbons ${ }^{\mathrm{a}}$ \\ a Laboratorio de Reproducción de Rumiantes Menores, INTA Bariloche, San Carlos de Bariloche, Argentina \\ ${ }^{\mathrm{b}}$ Facultad de Ciencias Veterinarias, Universidad Nacional de la Plata, Argentina \\ ${ }^{\mathrm{c}}$ Laboratorio de Regulación Hipofisaria, Instituto de Biología y Medicina Experimental-CONICET, Buenos Aires, Argentina
}

\section{A R T I C L E I N F O}

\section{Article history:}

Received 3 July 2017

Received in revised form

13 September 2017

Accepted 16 September 2017

Available online 23 September 2017

\section{Keywords:}

GnRH

hCG

Corpus luteum

Follicle

Progesterone

\begin{abstract}
A B S T R A C T
We determined the effect of GnRH or hCG treatment on day 4 post-time artificial insemination (FTAI) on the formation of accessory corpora lutea (acc-CL) and on the concentration of serum progesterone $\left(\mathrm{P}_{4}\right)$ in sheep. Multiparous adult Merino ewes $(\mathrm{n}=36)$ were synchronized for estrus using double injection of PGF2 $\alpha$ agonist (125 $\mu \mathrm{g}$ Cloprostenol) with an interval of 14 days. At $53-56 \mathrm{~h}$ after the second PG application, FTAI was performed. On day 4 post FTAI, ewes were either treated with analogue of GnRH ( $4 \mu \mathrm{g}$ buserelin; $\mathrm{n}=12$ ) or hCG (300 IU, hCG; $\mathrm{n}=12$ ) or saline solution $(1 \mathrm{ml}$; Control; $\mathrm{n}=12$ ). Two laparoscopic ovarian examinations were performed on days 4 and 10 post FTAI. In the first observation, we determined the number of post ovulation corpora lutea (po-CL) and the site, number and diameter of follicles present in both ovaries. In the second laparoscopy, we observed the number of po-CL and acc-CL. The sizes of the follicles that generated the acc-CL were determined according to the position of the follicles observed in the first laparoscopy. Serum $\mathrm{P}_{4}$ concentration was determined on days $4,7,10,13,17$ and 21 post FTAI by chemiluminescence. A similar follicular population in size and number was observed in the three experimental groups prior to the beginning of treatments (Follicles $2 \mathrm{~mm}: 6.4 \pm 3.7,3 \mathrm{~mm}$ : $\left.3.0 \pm 2.3,4 \mathrm{~mm}: 1.1 \pm 0.5,5 \mathrm{~mm}: 1.4 \pm 0.8 ; \mathrm{P}^{>} 0.05\right)$. The formation of $1.0 \pm 0.4$ and $1.1 \pm 0.3$ acc-CL was observed in the GnRH and hCG groups, respectively ( $P>0.05$ ), but was not observed in the Control group $(\mathrm{P}<0.05)$. Follicle sizes from which acc-CL generated were 3,4 and $5 \mathrm{~mm}$ and did not differ between hormonal treatments $(P>0.05)$. The hCG group had higher mean concentrations of $P_{4}$ on days $7,10,13$ and 17 post FTAI compared with the GnRH group and the Control group $(\mathrm{P}<0.05)$, while no differences were observed between these two latter groups $(\mathrm{P}>0.05)$. Mean $\mathrm{P}_{4}$ concentrations in ewes treated with hCG showed no differences according to the size of the follicle from which acc-CL were generated ( $P>0.05$ ). In conclusion, administration of hCG or GnRH on day 4 post FTAI induced the formation of one acc-CL from follicles of 3,4 or $5 \mathrm{~mm}$, indistinctly. However, serum $\mathrm{P}_{4}$ concentration increased significantly only in the hCG group. The serum $\mathrm{P}_{4}$ concentrations of acc-CL that originated from different follicle sizes did not differ.
\end{abstract}

(c) 2017 Published by Elsevier Inc.

\section{Introduction}

The main losses during gestation in sheep occur in the embryonic period and constitute a multicausal reproductive problem. Inadequate luteal function is one of the most relevant causes of

\footnotetext{
* Corresponding author

E-mail address: fernandez.jimena@inta.gob.ar (J. Fernandez).
}

pregnancy failure in sheep [1]. Insufficient progesterone $\left(\mathrm{P}_{4}\right)$ production by the corpus luteum (CL), such as suboptimal $\mathrm{P}_{4}$ synthesis, is indicative of maternal inability to maintain pregnancy [2]. The $\mathrm{P}_{4}$ is required for the establishment and maintenance of pregnancy in all mammals. Also growth and development of the conceptus (embryo/fetus and associated extraembryonic membranes) needs $\mathrm{P}_{4}$ signaling to regulate endometrial functions critical for implantation and placentation [3]. 
Different therapeutic strategies have been used with the objective of increasing the concentration of $\mathrm{P}_{4}$ and improving luteal function. Hormonal treatments in sheep were carried out in different breeds, animal categories and seasons of the year, using luteotrophic hormones, such as gonadotrophin releasing hormone $(\mathrm{GnRH})$ or human chorionic gonadotrophin (hCG) in the early luteal phase [4-8] as in the late luteal phase [9-12]. The hCG has an activity similar to luteinizing hormone (LH), while the GnRH acts on pituitary gland, stimulates the release of LH and follicle-stimulating hormone (FSH) and subsequently the secretion of steroid hormones from the gonads. These hormones when administrated in the luteal phase act indirectly or directly on the ovary generating the formation of an accessory corpus luteum (acc-CL) and increasing the serum $\mathrm{P}_{4}$ concentration [6,12-14]. Increased $\mathrm{P}_{4}$ is known to improve embryonic survival and to reduce embryonic losses in ruminants [4,15-17]. However, results of hormonal treatments performed under different experimental conditions are variable, contradictory and often inconclusive.

Besides in ewes, the relationship between follicle size and subsequent CL size has not been studied, as has been in cows; data in this species suggest that a large CL generates from a large follicle, which would provide high $\mathrm{P}_{4}$ concentration to favor embryo development [18]. Therefore, the objective of this study was to evaluate the effect of the administration of hCG or GnRH on day 4 post fixed-time artificial insemination (FTAI) on the formation of acc-CL in relation to follicle size and on the concentration of $\mathrm{P}_{4}$ in Merino sheep during the reproductive season in Northern Patagonia, Argentina.

\section{Materials and methods}

\subsection{Animals and handling}

The experiment was conducted at the Farm Research Unit of the National Institute of Agricultural Technology, Bariloche, Río Negro $\left(41^{\circ} 7^{\prime} 23^{\prime \prime} \mathrm{S}, 70^{\circ} 43^{\prime} 12^{\prime \prime} \mathrm{W}\right)$, during breeding season (May-June). Ethical concerns were taken into account by adhering to local animal welfare regulations and practices by the International Guiding Principles for Biomedical Research Involving Animals Committee (Comité Institucional de Cuidado y Uso de Animales de Laboratorio [CICUAL]; Facultad de Ciencias Veterinarias, Universidad Nacional de La Plata, La Plata, Argentina). Protocol number for the Use of Animals of Scientific Research is 53-6-15T.

Thirty-six adult multiparous Merino sheep, mean body weight of $48.7 \pm 5.7 \mathrm{~kg}$ and body condition of $2.5 \pm 0.2$ (subjective scale, 1 emaciated, 5 obese; [19]) were included in the experiment. The animals were maintained under natural grazing and with free access to water. All animals were estrus synchronized by the administration of two doses of prostaglandin F2 $\alpha$ (PGF, $125 \mu \mathrm{g}$ Cloprostenol, im; Cyclase, Syntex, Argentina) with an interval of 14 days. At 53-56 h after the second PG application, FTAI was performed vaginally with $0.03 \mathrm{ml}$ of fresh semen with a mean concentration of 100 million spermatozoa per insemination dose [20]. Fresh semen was previously collected with an artificial vagina from one clinically healthy adult Merino ram of proven fertility (Breeding Soundness Examination and test for Brucella ovis). All the ewes were inseminated with the same ram.

On day 4 post FTAI, ewes were assigned randomly to three experimental groups: GnRH group ( $\mathrm{n}=12 ; 4 \mu \mathrm{g}$ of Buserelin; im; Receptal, Intervet, Argentina), hCG group ( $\mathrm{n}=12 ; 300 \mathrm{IU}$ of $\mathrm{Hcg}$; $\mathrm{im}$; Gonacor ${ }^{\mathbb{B}}$, Ferring, Argentina) and Control group $(\mathrm{n}=12 ; 1 \mathrm{ml}$ of saline solution; im).

\subsection{Ovarian observation}

Two laparoscopic ovarian examinations were performed on days 4 and 10 post FTAI in all the animals from each experimental group. In the first laparoscopic examination, the number of post ovulation corpora lutea (po-CL) and the site, number and diameter of follicles present in both ovaries was determined. The diameter of all follicles $\geq 2 \mathrm{~mm}$ in size was measured with a manipulation probe engraved with a millimeter scale described by Cueto et al. [21]. The relative position of each follicle to other follicles and/or luteal structures was recorded in a diagram of the ovaries to evaluate the sizes of the follicles that generated the acc- CL at the second laparoscopy. In the second laparoscopic examination, the number of po-CL and acc-CL were determined. The sizes of the follicles that generated the acc-CL were determined according to the position of the follicles observed in the first laparoscopic examination.

To perform the laparoscopic examination, the ewes were deprived of food for $24 \mathrm{~h}$ and water for $12 \mathrm{~h}$. Laparoscopic examinations were carried out by placing ewes in dorsal recumbent position on a standard cradle for laparoscopic surgery. The procedure was carried out under im general anesthetic (xylazine, $0.2 \mathrm{mg} / \mathrm{kg}$, im; Kensol ${ }^{\circledR} 2 \%$, Konig, Argentina; ketamine clorhidrate $2.5 \mathrm{mg} / \mathrm{kg}$, $\operatorname{Ketalar}^{\circledR}$, Parke-Davis, Argentina). In addition, a local anesthetic (lidocaine, $1 \mathrm{ml}$, im; Frankaina ${ }^{\circledR} 2 \%$; Fatro Von Franken, Argentina) was administrated at the site of trocar insertion. For laparoscopic procedure, a trocar was located approximately $5 \mathrm{~cm}$ cranial to the udder and $5 \mathrm{~cm}$ to the left side of the midline. Afterwards, an endoscope (Richard Wolf, Knittlingen, Germany; $4 \mathrm{~mm}$ diameter; 170-mm length) was inserted into the abdominal cavity through a trocar to visualize the ovaries. The ovaries were handled by using a Veress needle placed in the midline (Endopath; Ethicon EndoSurgery, Cincinnati, OH, USA; 2-mm diameter; 120-mm length). Finally, the trocar orifices were treated with local antibiotic cicatrizing solution (Young Plata, Quimagro, Argentina) and a preventive antibiotic therapy was carried out $(1 \mathrm{ml} / 10 \mathrm{~kg}$ of PenicilinStreptomycin, Over, Argentina).

\subsection{Blood collection and serum progesterone assessment}

On days $4,7,10,13,17$ and 21 post FTAI, blood samples were collect by jugular venipuncture using vacuum tubes (BD Vacutainer ${ }^{\mathbb{B}}$, Franklin Lakes, NJ, USA). The samples were centrifuged for $15 \mathrm{~min}$ at $3000 \mathrm{rpm}$ and the serum obtained was stored at $-20^{\circ} \mathrm{C}$ until the time of analysis. Determination of serum $\mathrm{P}_{4}$ concentrations was performed by chemiluminescence immunoassay (Elecsys $^{\circledR}$, Progesterone II, Roche, Mannheim, Germany) with a sensitivity of $\leq 0.1 \mathrm{ng} / \mathrm{ml}$, a specificity $90 \%$ and an intra-assay and inter-assay coefficient of variation $<10 \%$ for samples between 0.1 and $36 \mathrm{ng} / \mathrm{ml}$.

\subsection{Statistical analysis}

Analysis of data was performed using R Commander [22]. The $\mathrm{P}_{4}$ serum concentrations in pregnant ewes were analyzed by ANOVA using a generalized linear model with time-repeated measurements. The number of acc-CL and the size of the follicles that generated the acc-CL were compared among treatment groups by one-way ANOVA and post-hoc comparison was made using Bonferroni post-tests. Statistical significance was accepted from $\mathrm{P}<0.05$.

\section{Results}

The number of $2-5 \mathrm{~mm}$ follicles at time of treatments was similar in all groups (Table $1 ; \mathrm{P}>0.05$ ). The GnRH and hCG treated 
groups had a higher number of acc-CL compared to the control group $(1.05 \pm 0.03$ vs. $0.00 \pm 0.00, \mathrm{P}<0.01)$. Furthermore, there were no differences in acc-CL formation between the GnRH and the hCG groups $(1.0 \pm 0.4$ vs. $1.1 \pm 0.3 ; \mathrm{P}>0.05)$. Follicle sizes from which acc-CL generated were 3,4 and $5 \mathrm{~mm}$ vs 4 and $5 \mathrm{~mm}$ for the GnRH and hCG groups, respectively and did not differ between groups $(\mathrm{P}>0.05)$. In pregnant ewes, mean concentrations of $\mathrm{P}_{4}$ on days $7,10,13$ and 17 post FTAI were higher in the hCG group $(4.1 \pm 1.3,10.5 \pm 2.0,9.4 \pm 1.9,7.4 \pm 2.1 \mathrm{ng} / \mathrm{ml})$ compared to the GnRH group $(2.3 \pm 1.1,5.6 \pm 2.5,5.6 \pm 2.9,5.7 \pm 1.8 \mathrm{ng} / \mathrm{ml})$ and the Control group $(2.5 \pm 1.1,5.3 \pm 4.5,5.2 \pm 3.2,4.8 \pm 2.5 \mathrm{ng} / \mathrm{ml})$ $\left(\mathrm{P}<0.01\right.$, Fig. 1). No differences in $\mathrm{P}_{4}$ concentrations were observed between the GnRH and Control groups ( $\mathrm{P}>0.05$, Fig. 2). Serum $\mathrm{P}_{4}$ concentrations in the hCG treated ewes were similar according to the size of the follicle from which the acc-CL was generated (P > 0.05, Fig. 2).

\section{Discussion}

The results of the present study showed that the administration of GnRH or hCG on day 4 post FTAI generated acc-CL in 91.6\% (11/ $12)$ and $100 \%(12 / 12)$ of the treated ewes, respectively. In agreement with these results, Hashem et al. [7] reported the formation of an acc-CL after the administration of $4 \mu \mathrm{g}$ of GnRH agonist on day 7 post estrus. Furthermore, Lankford et al. [6] reported the presence of two or more acc-CL after the application of 200 IU of hCG administered on days 4, 7 and 10 after the onset of estrus. These data all together, confirm the ability of these hormonal treatments to induce the formation of one or more acc-CL following treatment application.

This work is the first study to provide original insight on the size of follicles that generates acc-CL after the administration of GnRH o hCG. Our results show that acc-CL induced by luteotrophic hormonal treatments were generated from follicles of 3,4 and $5 \mathrm{~mm}$ in diameter, at the time of treatment application. The follicles that generated acc-CL were the largest found at first laparoscopic observation. In the case there were two large follicles of the same size, only one of them generated an acc-CL. This information is consistent with previous observations in monovular ewes in which the ovulatory follicle is the largest growing follicle present in both ovaries at the time of luteolysis, around 2-4 days before the onset of estrus [23]. Molecular studies on LH receptors demonstrated that mRNA for LH receptors was expressed in theca interna cells of antral follicles. During follicular growth, the level of LH receptor mRNA expression increased with follicle size and differences were observed in tissue preparation and identification of healthy follicles [24]. Our data confirm that there is a large variability in size from which the ovulatory follicle can be selected, since all follicles larger than $2 \mathrm{~mm}$ can be promoted to ovulate [25].

Results from the current study showed that the administration of hCG on day 4 post FTAI consistently increased plasma concentration of $\mathrm{P}_{4}$, confirming results from previous studies, which had reported that the application of hCG on days 6 or 9 [12], 3, 4 or 5 [5]

Table 1

Follicular population (Mean \pm standard error of the mean) in treated with an injection of $4 \mu \mathrm{g}$ of an analogue of gonadotrophin releasing hormone (GnRH), $300 \mathrm{IU}$ of human chorionic gonadotropin (hCG) or $1 \mathrm{ml}$ of saline solution (Control) at day 4 post fixed-time artificial insemination.

\begin{tabular}{lllll}
\hline Follicle Diameter & GnRH $(\mathrm{n}=12)$ & hCG $(\mathrm{n}=12)$ & Control $(\mathrm{n}=12)$ & P value \\
\hline $2 \mathrm{~mm}$ & $6.4 \pm 3.8$ & $6.7 \pm 4.0$ & $6.4 \pm 2.7$ & 0.9 \\
$3 \mathrm{~mm}$ & $3.1 \pm 2.9$ & $3.1 \pm 1.8$ & $2.2 \pm 1.5$ & 0.6 \\
$4 \mathrm{~mm}$ & $1.3 \pm 0.8$ & $1.0 \pm 0.0$ & $1.6 \pm 0.9$ & 0.2 \\
$5 \mathrm{~mm}$ & $1.2 \pm 0.5$ & $1.3 \pm 0.7$ & $1.6 \pm 0.5$ & 0.1 \\
\hline
\end{tabular}

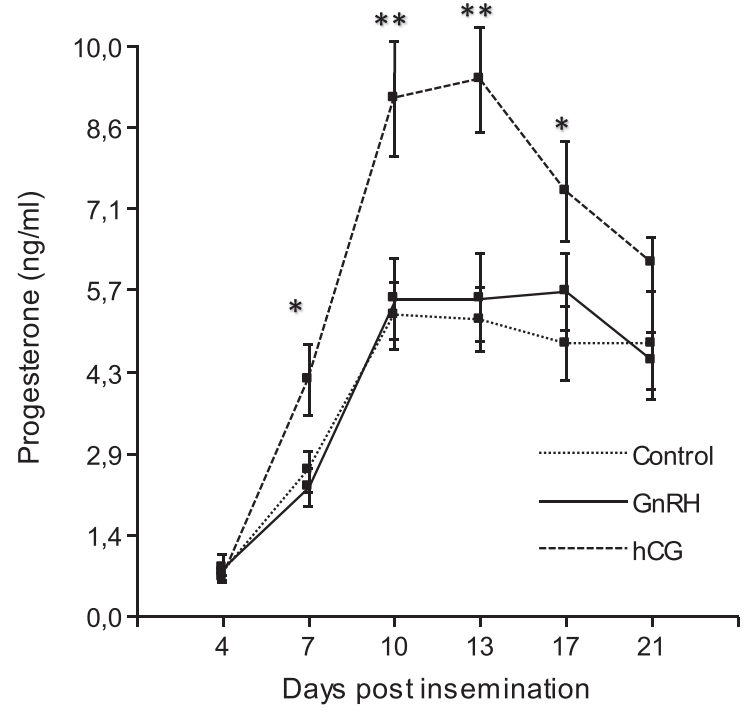

Fig. 1. Mean serum concentration of $\mathrm{P}_{4}$ on day 4, 7, 10, 13, 17 and 21 post fixed-time artificial insemination in pregnant ewes treated with $4 \mu \mathrm{g}$ of an analogue of gonadotrophin releasing hormone $(\mathrm{GnRH} ; \mathrm{n}=8), 300 \mathrm{IU}$ of human chorionic gonadotropin (hCG; $\mathrm{n}=8$ ) or $1 \mathrm{ml}$ saline solution (Control; $\mathrm{n}=11$ ) on day 4 post fixed-time artificial insemination. Days marked with an asterisk $\left(^{*}\right)$ indicate to differ between groups $(\mathrm{P}<0.05)$ and ${ }^{* *}$ indicate $\mathrm{P}<0.01$.

or 4, 7 and 10 post estrus [6] induced acc- CL and increased plasma concentration of $\mathrm{P}_{4}$ compared to untreated controls.

Serum $\mathrm{P}_{4}$ concentration in hCG treated ewes was not modified according to the size of the follicle from which the acc-CL were generated. This would indicate that regardless of the follicular size from which it originates, a functional $\mathrm{CL}$ is formed. In contrast, Binelli et al. [18] have reported in cows that the size of the dominant follicle is associated with the size of the subsequent $\mathrm{CL}$, which would provide higher $\mathrm{P}_{4}$ concentration. Future studies should be carried out on the size of the acc-CL and subsequent $\mathrm{P}_{4}$ concentration and its relationship with the size of the follicle from which

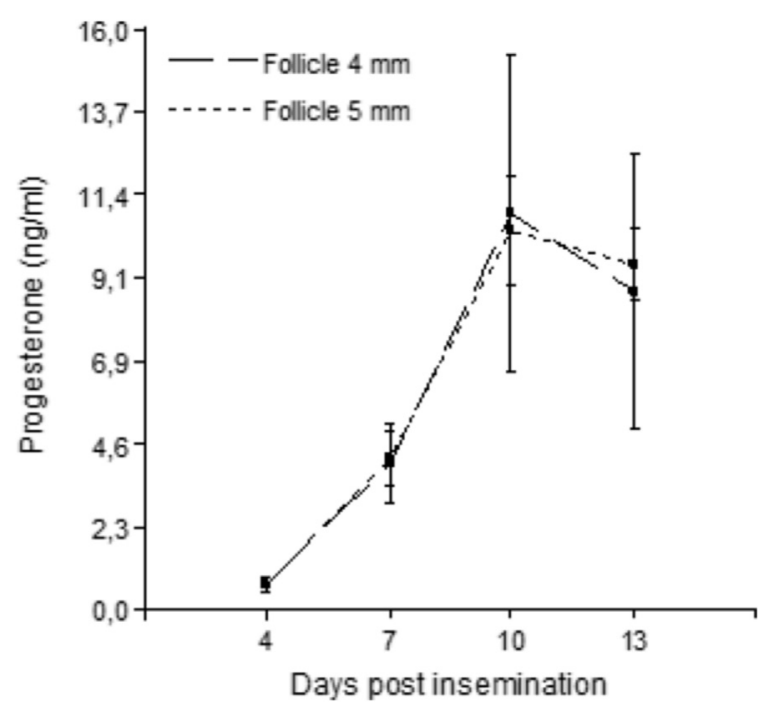

Fig. 2. Mean serum concentration of $\mathrm{P} 4$ on days $4,7,10$ and 13 post fixed-time artificial insemination in ewes treated with $300 \mathrm{IU}$ of human chorionic gonadotropin (hCG; $\mathrm{n}=12$ ) on day 4 post fixed-time artificial insemination according to the size of the follicle from which the acc-CL was generated. 
the acc-CL was generated.

However, in the present study, the administration of GnRH on day 4 post FTAI did not increase serum concentration of $\mathrm{P}_{4}$. These results are in contrast with previous findings in which $\mathrm{GnRH}$ agonist applied on the day of estrus [13,26] or on day 12 after mating $[14,27,28]$ increased post-treatment plasma $\mathrm{P}_{4}$ concentration. Differences among our results and prior data could be attributed to different experimental conditions such as the dose or the timing of $\mathrm{GnRH}$ injection, because in our study there were not adequate to increase concentrations of progesterone in serum.

It is noteworthy to point out the observation that ewes treated with hCG consistently had greater plasma $\mathrm{P}_{4}$ concentrations when compared with ewes treated with GnRH. Similar results were reported by Ishida et al. [12] after the application of hCG or GnRH on day 12 after CIDR removal, confirming higher $\mathrm{P}_{4}$ concentrations in ewes treated with hCG compared to ewes treated with GnRH. Possible explanations for this effect require further studies, but these findings could be related to differences in the dynamics of LHlike exposure as pharmacokinetics and pharmacodynamics of these two hormones, which in turn might induce the formation of $\mathrm{CL}$ with different steroidogenic abilities [15,29]. Whereas, some authors argue that a higher number of $\mathrm{CL}$ secrete more $\mathrm{P}_{4}[3,6,7]$; other authors support the idea that increased $\mathrm{P}_{4}$ concentration is due to the amount and capability of the steroidogenic tissue to produce $\mathrm{P}_{4}$ and not only to the number of $\mathrm{CL}[15,29]$.

The hCG acts directly on the receptors of LH in the ovary, inducing the differentiation of the follicular cells in luteal cells [4]. Since hCG has a longer half-life than $\mathrm{GnRH}$, it can persist longer in the circulation. Therefore, besides inducing the formation of acc-CL, hCG may exert luteotropic effects by directly stimulating $\mathrm{P}_{4}$ production, which may increase pregnancy rates [18]. Furthermore, given its luteotrophic nature, hCG also appears to stimulate the development of the original $C L$, giving rise to a double effect on $\mathrm{P}_{4}$ concentrations [26]. Farin et al. [4], treating ewes with $300 \mathrm{IU}$ of hCG on days 5 and 7.5 of the estrous cycle, detected an increase in the proportion of large steroidogenic luteal cells and a decrease in the proportion of small cells causing an increase in the area of luteal tissue and steroidogenic tissue capable of synthesizing $\mathrm{P}_{4}$ [30].

In a different way, GnRH had a main indirectly effect on ovary, acting on pituitary receptors to stimulate the release of $\mathrm{LH}$ (and FSH), which in turn acts on the ovary. Nevertheless, a direct action of GnRH on the ovary cannot be discarded as peripheral GnRH receptors are expressed in the granulosa cells of preovulatory follicles and also in the granulosa luteal cells [31]. However, the GnRH affinity to these receptors seems to be weaker than that for central receptors, and their activation by GnRH agonists have been shown to have antiproliferative/proapoptotic effects [32,33]. Webb et al. [34] reported in cows that a CL induced with GnRH could develop into a fully functional structure of normal weight and progesterone contents $7 \mathrm{~d}$ after induction, as compared with spontaneously formed $\mathrm{CL}$ of similar age. However, in primates, induction of ovulation with $\mathrm{GnRH}$ or a GnRH agonist promoted development of $\mathrm{CL}$ with suboptimal progesterone-secreting capacities when compared with the induction of ovulation with hCG [35]; thus supporting findings from the present study. A spontaneous occurring preovulatory LH-surge lasts $8-10 \mathrm{~h}$, whereas an induced $\mathrm{LH}-$ surge following administration of $\mathrm{GnRH}$ or $\mathrm{GnRH}$-agonist lasts only $3-5 \mathrm{~h}$ [36], probably producing an acc-CL unable to produce more $\mathrm{P}_{4}$. In this sense, Ambrose et al. [36] postulated that prolonged exposure of follicular theca and granulosa cells of the preovulatory follicle to high levels of LH could be crucial for the subsequent development of a robust $\mathrm{CL}$ capable of secreting more $\mathrm{P}_{4}$.

In conclusion, the results of the present study showed that administration of hCG or GnRH on day 4 post FTAI induces the formation of acc-CL from follicles equal or greater than $3 \mathrm{~mm}$ and increases serum concentration of $\mathrm{P}_{4}$, but only in animals treated with hCG. The increase of $\mathrm{P}_{4}$ serum concentration was not modified according to the size of the follicle from which the acc-CL were generated.

Future studies should be conducted to obtain more information on the scope of this therapeutic strategy in reproductive performance in order to justify its recommendation in artificial insemination or embryo transfer programs. Further information on the effect of these hormonal treatments in the ovary, uterus and embryo would help us to understand and amplify this specific effect to reduce embryonic losses and improve reproductive efficiency.

\section{Acknowledgment}

The present study was supported by the Project PNSA 115053 (INTA) and PICT 2012-2238 (FONCyT). The authors thank to the staff of the Experimental farm Pilcaniyeu of INTA Bariloche for assistance during the study.

\section{References}

[1] Nancarrow CD. Embryonic mortality in the ewe and doe. first ed. London: Zavy \& Geisart; 1994. p. 79-97.

[2] Kittok RJ, Stellflug JN, Lowry SR. Enhanced progesterone and pregnancy rate after gonadotropin administration in lactating ewes. J Anim Sci 1983;56: $652-5$.

[3] Coleson MP, Sanchez NS, Ashley AK, Ross TT, Ashley RL. Human chorionic gonadotropin increases serum progesterone, number of corpora lutea and angiogenic factors in pregnant sheep. Reproduction 2015;150:43-52.

[4] Farin CE, Moeller CL, Mayan H, Gamboni F, Sawyer HR, Niswender GD. Effect of luteinizing hormone and human chorionic gonadotrophin on cell populations in the ovine corpus luteum. Biol Reprod 1988;38:413-21.

[5] Fukui Y, Itagaki R, Ishida N, Okada M. Effect of different hCG treatments on fertility of estrus-induced and artificially inseminated ewes during the nonbreeding season. J Reprod Dev 2001;47:189-95.

[6] Lankford LM, Yates DT, Halalsheh RA, Black PL, Hallford DM, Ross TT. Effects of human chorionic gonadotropin on serum progesterone concentrations, embryonic survival, and lambing rates in ewes. Proceeding West Sect Am Soc Anim Sci 2010;61:153-7.

[7] Hashem NM, El-Azrak KM, El-Din AN, Taha TA, Salem MH. Effect of GnRH treatment on ovarian activity and reproductive performance of low-prolific Rahmani ewes. Theriogenology 2014;83:192-8.

[8] Nephew KP, Cárdenas H, McClure KE, Ott TL, Bazer FW, Pope WF. Effects of administration of human chorionic gonadotropin or progesterone before maternal recognition of pregnancy on blastocyst development and pregnancy in sheep. J Anim Sci 1994;72:453-8.

[9] Cam MA, Kuran M. Effects of a single injection of hCG or GnRH agonist on day 12 post mating on fetal growth and reproductive performance of sheep. Anim Reprod Sci 2004;80:81-90

[10] Khan TH, Beck NFG, Khalid M. The effect of hCG treatment on day 12 postmating on ovarian function and reproductive performance of ewes and ewe lambs. Anim Reprod Sci 2009;116:162-8.

[11] Moeini MM, Alipour F, Sanjabi MR. Efficacy of CIDR or FGA sponges with hCG treatments on the conception rate and prolificacy in Lori Ewes out of the breeding season. Iran J Appl Anim Sci 2013;3:521-5.

[12] Ishida N, Okada M, Sebata K, Minato M, Fukui Y. Effect of GnRH and hCG treatments for enhancing corpus luteum function to increase lambing rate of ewes artificially inseminated during the non-breeding season. J Reprod Dev $1999 ; 45: 73-9$

[13] Cavalcanti ADS, Brandão FZ, Nogueira LAG, Fonseca JFD. Effects of GnRH administration on ovulation and fertility in ewes subjected to estrous synchronization. Rev Bras Zoot 2012;41:1412-8.

[14] Lashari MH, Tasawar Z. The effect of GnRH (Dalmarelin) given on Day 12 postmating on ovarian function and embryo development in Lohi sheep at southern. Pak J Life Soc Sci 2013:11:165-70.

[15] Schmitt EJ, Diaz T, Barros CM, De la Sota RL, Drost M, Fredriksson EW, et al. Differential response of the luteal phase and fertility in cattle following ovulation of the first-wave follicle with human chorionic gonadotropin or an agonist of gonadotropin-releasing hormone. J Anim Sci 1996;74:1074-83.

[16] Khan TH, Beck NFG, Khalid M. The effects of GnRH analogue (buserelin) or hCG (Chorulon) on day 12 of pregnancy on ovarian function plasma hormone concentrations conceptus growth and placentation in ewes and ewe lambs. Anim Reprod Sci 2007;102:247-57.

[17] Rostami B, Hajizadeh R, Shahir MH, Aliyari D. The effect of post-mating hCG or progesterone administration on reproductive performance of Afsharix Booroola-Merino crossbred ewes. Trop Anim Health Prod 2016;3:1-6.

[18] Binelli M, Thatcher WW, Mattos R, Baruselli PS. Antiluteolytic strategies to improve fertility in cattle. Theriogenology 2001;56:1451-63. 
[19] Russel AJF, Doney JM, Gunn RG. Subjective assessment of body fat in live sheep. J Agric Sci 1969;72:451-4.

[20] Cueto MI, Gibbons AE. Inseminación artificial cervical en ovejas sincronizadas con prostaglandinas. Rev Presencia 2011;58:15-9.

[21] Cueto M, Gibbons A, Alberio R, Taddeo H, González-Bulnes A. Timing of emergence of ovulatory follicles in polyovulatory goats. Anim Reprod. Sci 2006;91:275-84.

[22] R Core Team. R: a language and environment for statistical computing. Vienna, Austria: R Foundation for Statistical Computing; 2016. http://www.Rproject.org/.

[23] González Bulnes A, Santiago Moreno J, García García RM, del Campo A, López Sebastian A. Origin of the preovulatory follicle in Mouflon sheep (Ovis gmelini musimon) and effect on growth of remaining follicles during the follicular phase of oestrous cycle. Anim Reprod Sci 2001;65:265-72.

[24] Xu Z, Allen Garverick H, Smith GW, Smith MF, Hamilton SA, Youngquist RS. Expression of follicle-stimulating hormone and luteinizing hormone receptor messenger ribonucleic acids in bovine follicles during the first follicular wave. Biol reprod 1995;53:951-7.

[25] Tsonis CG, Cahill LP, Carson RS, Findlay JK. Identification at the onset of luteolysis of follicles capable of ovulation in the ewe. J Reprod Fert 1984;70: 609-14.

[26] Sirjani MA, Shahir MH, Kohram H, Shahneh AZ. Effect of gonadotropinreleasing hormone $(\mathrm{GnRH})$ treatment on multiple births in Afshari ewes. Afr J Biotech 2011;10:12358-62.

[27] Beck NFG, Jones M, Davies B, Mann GE, Peters AR. The effect of GnRH analogue (buserelin) treatment on day 12 post-mating on ovarian structure and plasma progesterone and oestradiol concentration in ewes. Anim Sci 1996;63: 407-12.

[28] Cam MA, Kuran M, Yildiz S, Selcuk E. Fetal growth and reproductive performance in ewes administered GnRH agonist on day 12 post-mating Anim Reprod 2002;72:73-82.

[29] Maillo V, Duffy P, O'Hara L, de Frutos C, Kelly AK, Lonergan P, et al. Effect of hCG administration during corpus luteum establishment on subsequent corpus luteum development and circulating progesterone concentrations in beef heifers. Reprod Fertil Dev 2013;26:367-74.

[30] Castro ACR, Arashiro EKN, Zambrini FN, Guimarães ASL, Esteves LV, Fonseca JF. Effect of hCG administration on accessory corpus luteum formation and area in estrous induced nulliparous Santa Inês ewes. Anim Reprod 2015;21:148.

[31] Choi JH, Gilks CB, Auersperg N, Leung PC. Immunolocalization of gonadotropinreleasing hormone (GnRH)-I, GnRH-II, and type I GnRH receptor during follicular development in the human ovary. J Clin Endocrinol Metab 2006;91: $4562-70$.

[32] Yu B, Ruman J, Christman G. The role of peripheral gonadotropin-releasing hormone receptors in female reproduction. Fertil Steril 2011;95:465-73.

[33] So WK, Cheng JC, Poon SL, Leung PC. Gonadotropin-releasing hormone and ovarian cancer: a functional and mechanistic overview. FEBS I 2008;275: 5496-511.

[34] Webb R, Gong JG, Law AS, Rusbridge SM. Control of ovarian function in cattle. J Reprod Fertil 1992:45(Suppl):141-56.

[35] Zelinski-Wooten MB, Lanzerdorf SE, Wolf DP, Chandrasecker AY, Stouffer RL. Titrating luteinizing hormone surge requirements for ovulatory changes in primate follicles. I. Oocyte maturation and corpus luteum function. J Clin Endocrinol Metab 1991;73:577-83.

[36] Ambrose JD, Pires MFA, Moreira F, Diaz T, Binelli M, Thatcher WW. Influence of deslorelin (GnRH-agonist) implant on plasma progesterone, first wave dominant follicle and pregnancy in dairy cattle. Theriogenology 1998;50: 1157-70. 